\title{
Isolated Laryngeal Amyloidosis Nodular: A Case Report
}

\author{
Amiloidose Laríngea Nodular Isolada: Relato de Caso
}

\author{
Ricardo Rodrigues Figueiredo*, Andréia Aparecida de Azevedo**. \\ * Master in General Surgery-Otorhinolaryngology, Federal University of Rio de Janeiro. Associate Professor and Head of the Department of Otolaryngology, Faculty \\ of Medicine of Valencia. \\ ** Otorhinolaryngologist. OTOSUL of ENT, ENT South Fluminense. \\ Institution: OTOSUL, Otorhinolaryngology South Fluminense. \\ Volta Redonda / RJ - Brazil. \\ Mail Address: Ricardo Rodrigues Figueiredo - Rua 40, No. 20 - Salas 216-218 - Vila Santa Cecilia - Volta Redonda / RJ - Brazil - Zip code: 27255-650 - Telephone: \\ (+55 24) 3348-6382 - rfigueiredo @OTOSUL com.br \\ Article received in April 13, 2009. Article accepted in July 4, 2009.
}

\section{SUMMARY}

Introduction:

Objective:

Case report:

Final Comments: The isolated amyloidosis of the larynx, although rare, should always be entertained by the otolaryngologist,

Keywords:

Isolated amyloidosis of the larynx is rare, being the single most common location in head and neck. Can be divided into diffuse and nodular, and the surgical treatment priority.

To describe a case of isolated nodular amyloidosis of the larynx, with review of literature.

A female patient, 23 years, presented with complaints of dysphonia and cervical cake for about three months. A laryngoscopy revealed a polypoid lesion of large volume in the left vocal cord. Underwent microsurgery for the removal of the larynx, the histopathological report was consistent with amyloidosis, and underwent further simplified for clinical research locations extralaryngeal of amyloidosis, which was negative. It remains in clinical and laryngoscopic semester. since it is the most frequent clinical presentation of disease in head and neck, often indistinguishable in appearance to that of other benign lesions. It is indispensable for research extralaryngeal demonstrations.

\section{RESUMO}

Introdução: amyloidosis, larynx, laryngeal diseases.

Objetivo:

Relato do Caso:

A amiloidose isolada da laringe é rara, sendo a localização isolada mais comum em cabeça e pescoço. Pode ser dividida em difusa e nodular, sendo o tratamento prioritariamente cirúrgico.

Descrever um caso de amiloidose nodular isolada de laringe, com revisão da literatura.

Paciente do sexo feminino, 23 anos, apresentou-se com queixas de bolo cervical e disfonia há cerca de 3 meses. A videolaringoscopia revelou lesão de aspecto polipoide de grande volume em prega vocal esquerda. Submetida à remoção por microcirurgia de laringe, o laudo histopatológico foi compatível com amiloidose, sendo submetida à investigação clínica adicional simplificada para localizações extralaríngeas de amiloidose, a qual foi negativa. Permanece em acompanhamento clínico e laringoscópico semestral.

Comentários Finais: A amiloidose isolada da laringe, apesar de rara, deve ser sempre cogitada pelo otorrinolaringologista, uma vez que se trata da apresentação clínica mais frequente da doença em cabeça e pescoço, com aspecto muitas vezes indistinguível ao de outras lesões benignas. É indispensável a investigação para manifestações extralaríngeas.

Palavras-chave: amiloidose, laringe, doenças da laringe. 


\section{INTRODUCTION}

Amyloidosis consists of an idiopathic disease characterized by extracellular deposits of insoluble fibrillar protein (amyloid) in various tissues and organs (1). Were described 25 distinct biochemical forms, the most common forms AL (immunoglobulin light chains) and AA (serum amyloid disease) (2). Clinical forms can be divided into systemic amyloidosis (more common) and localized $(3,4)$. The localized forms affect mainly the abdominal organs (most frequently) and structures of the head and neck, especially the larynx, most common site of isolated amyloidosis in the head and neck (3). Amyloidosis accounts for about $1 \%$ of benign tumors of the larynx $(1,4,5,6)$.

Laryngeal amyloidosis is rare, having been first recognized on postmortem examination in 1842 (7.8). The first clinical report date of 1875 (7) and from then until 1990 , about 300 cases have been reported $(3,4)$.

Clinically, this disease is more common in males (3:1) and in the fifth decade of life $(3,6,8)$. The symptoms include hoarseness, dyspnea, dysphagia, and hemoptysis $(4,6,8)$. The appearance at laryngoscopy may be nodular or diffusely infiltrative (1.9) being the most frequent lesions in supraglottic (3). The most common locations, in descending order of frequency, are: ventricular, VF, vocal folds, ari-epiglottic folds and subglottis $(8,10,11,12,13)$.

Computed tomography may reveal thickening of the soft tissues of the larynx, with high density (14). Magnetic resonance has the same sign of skeletal muscle (15).

The differential diagnosis includes benign laryngeal tumors (especially polyps) and malignant tumors, and granulomatous diseases (5). Some authors believe that some cases Laryngocele might be caused by laryngeal amyloidosis $(9,14)$.

The clinical treatment, including steroids and radiation therapy, was ineffective (8). Treatment is by surgical removal of the lesion by laryngeal microsurgery (4). The external approach is reserved for cases with more extensive lesions $(1,8)$. The diagnostic confirmation by biopsy shows the microscopic appearance of deposits of an extracellular matrix, sub-epithelial, acellular eosinophilic, possibly associated with infiltration of lymphocytes, plasma cells and giant cells foreign body (2.5). In staining with congo red, there is birefringence type "apple green" typical $(3,5)$. Immunohistochemistry and electron microscopy are helpful in differentiating biochemical forms (2.6).

In some cases of extensive disease without imminent

\section{Chart I. Research for systemic amyloidosis.}

- $\mathrm{CBC}$

- tests of renal and hepatic function

- urine testing for Bence-Jones protein

- chestX-ray

- echocardiogram

- biopsies (rectum, abdominal fat, lips, kidneys, liver, bone marrow, skin)

airway obstruction, an expectant approach may be considered $(8,12)$.

Laryngeal amyloidosis is a slowly progressive disease rarely associated with systemic disease (1). Some authors recommend, in order to rule out other diseases such as systemic amyloidosis, multiple myeloma and plasmacytoma extracellular, a thorough investigation and detailed (Table 1) $(1,2,4,5,6)$.

Other authors, however, believe that, by nature isolated and slowly progressive laryngeal amyloidosis, patients without other clinical manifestations can only perform complete blood count and tests of renal and hepatic functions, remains under regular control of the laryngeal lesion by laryngoscopy (8).

\section{Case Report}

A 23-year-old white, assist in education, with complaints of dysphonia and mild pharyngeal discomfort for about three months. A laryngoscopy revealed massive grayish-white lesion in the left vocal cord. The lesion behavior tilting (displacement supraglottic, glottis, subglottis) during inspiration and phonation, allowing good glottal closure and, therefore, reasonable voice quality (Figures 1 and 2).

Made a preoperative diagnosis of vocal fold polyp, underwent laryngeal microsurgery under general anesthesia. The lesion was completely removed with a scalpel and cold microscissors, the material was sent for histopathology.

Histological sections revealed tissue segment, showing extensive areas of amorphous eosinophilic appearance, partially covered by stratified squamous epithelium. The congo red-staining revealed characteristic staining of amyloid substance.

On the 15th postoperative day the patient reported significant relief symptomatology. Videolaryngoscopy showed only slight infiltration in the mucosa, the insertion 


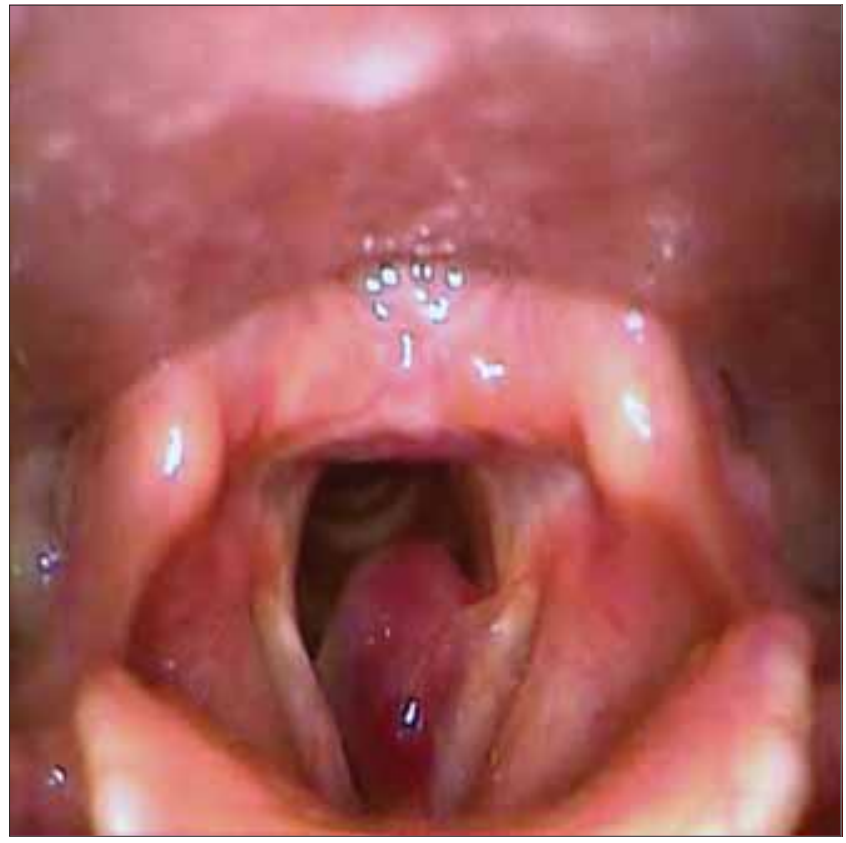

Figure 1. Tumor on the left vocal cord.

site of the lesion. As the patient had no other clinical manifestations, it was decided to carry out tests of CBC and renal and liver functions, which were normal and follow up every six months. Was referred to speech therapy complementary, since that makes use professional voice.

\section{DISCUSSION}

Our case corresponds to the rarest form of amyloidosis, the isolated location and the larynx is more frequent in head and neck. Does not fit the demographics most common (men in the fifth decade of life), or location laryngeal more frequent (supraglottic) $(3,6,8)$. The symptoms correspond to that described in the literature (dysphonia and pharyngeal discomfort) $(4,6,8)$.

Videolaryngoscopy suggested glottal polypoid lesion and the diagnosis of amyloidosis exclusively histopathology . Because the laryngeal disease manifestation alone, there was no clinical evidence to suspect amyloidosis, which highlights its importance as a differential diagnosis of laryngeal tumors (5). Laryngeal amyloidosis can present clinically similar to several other benign and should always be entertained in the differential diagnosis.

Despite the large size of the lesion, its removal from cold, with a scalpel and microscissors was relatively easy, it is not necessary using the laser, as suggested by some

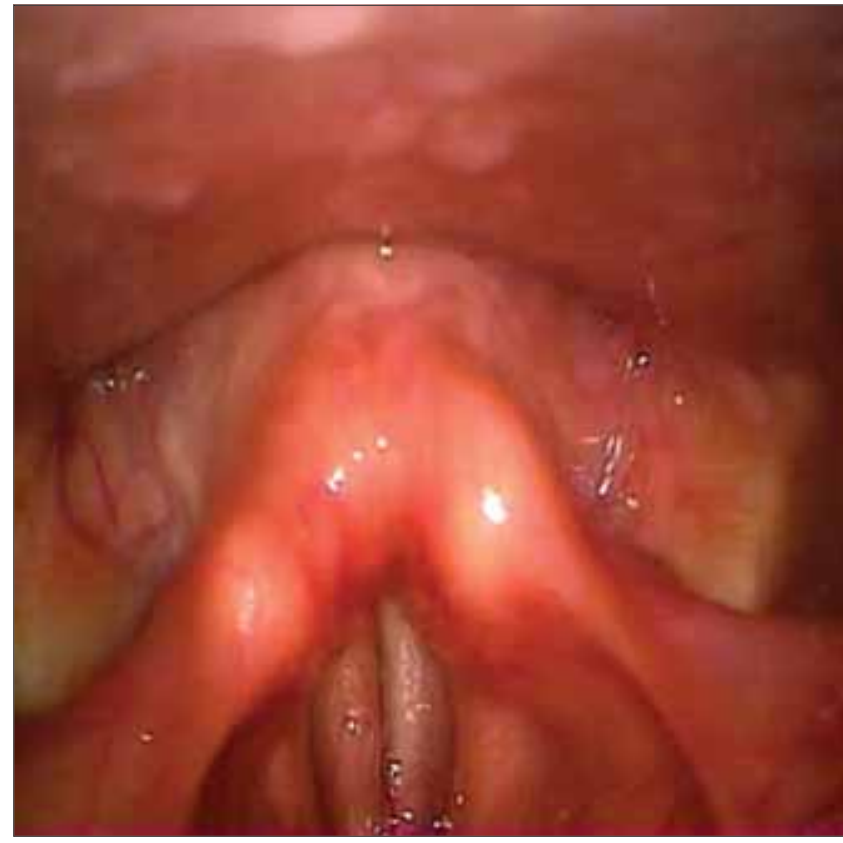

Figure 2. Larynx same patient during the phonatory phase, with good glottal closure. The lesion is in the subglottic space.

authors $(1,3)$. The injury should, wherever possible, be completely removed (excisional biopsy). It's important to send the material for a Service of Pathology trust, avoiding diagnostic errors.

The question is perhaps the most controversial research Postoperative we chose the simplified routine (complete blood count and renal function tests and liver) (8), because no other clinical manifestations. We emphasize the issue of monitoring every six months by biopses for early diagnosis of possible recurrence.

\section{FINAL COMMENTS}

Laryngeal amyloidosis, although rare, should always be entertained in the differential diagnosis of laryngeal masses, since it is disease indistinguishable from benign lesions, the clinical point of view. Treatment is mostly surgical (excisional biopsy), should be resorted to reliable service Pathology for histopathologic diagnosis. It is indispensable for research demonstrations extralaryngeal.

\section{ACKNOWLEDGEMENTS}

Dr Lorelei Luder, pathologist, Laboratory Pasteur, Volta Redonda. 
The Joao Alfredo Figueiredo, for the preparation of the images.

\section{Bibliographical ReFERENCES}

1. Pribtikin E, Friedman O, OHara B, Cunnane MF, Levi D, Rosen M, Keane WM, Sataloff RT. Amyloidosis of the upper aerodigestive tract. Laryngoscope. 2003, 113:20952101.

2. Penner CR, Müller S. Head an neck amyloidosis: a clinicopathologic study of 15 cases. Oral Oncol. 2006, 42:421429.

3. Motta G, Salzano FA, Motta S, Staibano S. CO2-laser treatment of laryngeal amyloidosis. J Laryngol Otol. 2003, 117:647-650.

4. Valera FCP, Fomin DS, Maggioni Jr GS, Grellet M. Amiloidose localizada laríngea: relato de caso e revisão de literatura. Rev Bras Otorrinolaringol. 2004, 70(3):423-426.

5. Akst L, Thompson LDL. Larynx amyloidosis. Ear Nose Throat J. 2003, 82(11):844-845.

6. Benning S, Technau-Ihling K, Fisch P, Fradis M, Schipper J, Maier W. Amyloid tumor of the larynx associated with plasma cell infiltration: Differential diagnosis. Ear Nose Throat J. 2004, 83(12):839-843.

7. Borrow A, Neumann L. Amiloide degeneration von larynx tumoren, canule sieben jahre lang getragen. Arch Kilin Chir. $1875,18: 242-246$.

8. Alaani A, Warfield AT, Path FRC, Pracy JP. Management of laryngeal amyloidosis. J Laryngol Otol. 2004, 118:279283.

9. Çankaya H, Egeli E, Ünal Ö, Kiris M. Laryngeal amyloidosis: a rare cause of laryngocele. J Clin Imag. 2002, 26:86-88.

10. Barnes EL, Zafer T. Laryngeal amyloidosis: clinocpathology study of seven cases. Ann Otol Rhinol Laryngol. 1977, 86:856-863.

11. Mitrani M, Biller HF. Laryngeal amyloidosis. Laryngoscope. 1985, 95:1346-1347.

12. Desuter G, Hamoir H, Van Geem C, Boucquey D. Laryngeal amyloidosis: a case of adidas-stripes larynx. Ear Nose Throat J. 2007, 85:378.

13. Sataloff R, Abaza M, Abaza NA, Markiewicz A, Hawkshaw M. Amyloidosis of the larynx. Ear Nose Throat J. 2001,80:389390.

14. Aydin O, Ustundag E, Iseri M, Ozkarakas H, Oguz A. Laryngeal amyloidosis with laryngocele. J Laryngol Otol. 1999, 113:361-363.

15. Gean-Marton AD, Kirsch CF, Vezina IG, Weber AL. Focal amyloidosis of the head and neck: evaluation with the CT and MR imaging. Radiology. 1991, 181(2):521-5. 